\title{
Primary brain hydatosis
}

\author{
Fariba Binesh, ${ }^{1}$ Mohamadreza Mehrabanian, ${ }^{2}$ Hossein Navabiii ${ }^{3}$ \\ ${ }^{1}$ Department of Pathology, Yazd Shahid Sadoghi University, Yazd, Islamic Republic of Iran; \\ 2Department of Neurosurgery, Yazd Shahid Sadoghi University, Yazd, Islamic Republic of Iran; \\ ${ }^{3}$ Yazd Shahid Sadoghi University, Yazd, Islamic Republic of Iran \\ Correspondence to Dr Hossein navabii, navabii@aol.com
}

\section{Summary}

The authors present a case of intracranial hydatid cyst presented with severe headache, nausea and vomiting. Radiological investigations, including CT scan and MRI revealed a solitary cyst in the right temporal lobe, paraventricular area. Total excision of the cyst was done. The features of this rare disease are retrospectively analysed in this presentation and the literature is reviewed.

\section{BACKGROUND}

Human infection with larval stages of tapeworms of the genus Echinococcus may take one of the three forms: unilocular hydatid disease caused by Echinococcus granulosus, multilocular or alveolar disease caused by Echinococcus multilocularis and polycystic hydatid disease caused by Echinococcus vogeli. Members of the dog family are definitive hosts for these minute tapeworms. Eggs are passed in the stools and ingested by the intermediate hosts, which include sheep, cattle, pigs, rodents and other herbivorous animals. Humans, especially children are infected.

Following the accidental ingestion of eggs from environment, the eggs hatch in the intestine and the embryo penetrate the intestinal wall and then enter the blood stream. Although most hydatids develop in the liver, some disseminated to other sites. These may even reach the brain. ${ }^{1}$ Larval stage of the cesto can involve the brain via the choroid plexus. ${ }^{2} 3$ Cerebral hydatid cyst are usually localised within the watershed zone of the middle cerebral arteries, often in the parietal lobe. ${ }^{45}$ Cerebral hydatid cysts are usually single, spherical and unilocular. ${ }^{67}$ Its incidence is $1-2 \%$ of all cases with hydatid disease. This case is reported for its rarity as well as certain unique features of the illness. Brain hydatidosis is an important differential diagnosis of intracranial cystic lesions in endemic regions, for example, the Middle-Eastern countries.

\section{CASE PRESENTATION}

An 18-year-old Iranian girl presented with complaints of diffuse episodic headache for the past 1 month that had increased in intensity over the past 2 weeks and was associated with nausea and vomiting. There was no history of seizures, trauma, surgery or any history of hydatidosis. She did not hail from an agricultural background and did not own a pet dog. Clinical examination revealed mydriasis, the rest of the neurological examination was normal. Haematological results were: haemoglobin $=12 \mathrm{~g} / \mathrm{dl}$, white blood cell count $=7500 / \mu 1$ with differential count of neutrophils $=55 \%$, lymphocytes $=42 \%$, band cells $=2 \%$ and eosinophils $1 \%$. MRI of brain showed cystic lesion with cerebrospinal fluid (CSF) intensity in the right temporal lobe, paraventricular area (figure 1). In thorax and abdominal CT scans, there was no cystic lesion. The brain cyst had hypodense wall and did not enhance with contrast (Omnipaque). Parietal craniotomy and removal of cyst were done under general anaesthesia. Cytopathological examination (including intraoperative squash preparation) confirmed hydatid disease (figures 2 and 3). Postoperative (1 month later) MRI showed no evidence of residual disease.

\section{DIFFERENTIAL DIAGNOSIS}

Imaging findings are usually suggestive (such as our case) but in some cases there are some pitfall in accurate diagnosis and such cases are difficult to differentiate from other cystic lesions such as abscesses, large granulomas, cystic gliomas, epidermal cysts and arachnoid cysts.

\section{TREATMENT}

As a first step, neurosurgical intervention was made to remove the cyst without rupture. Pathological examination of the specimen confirmed the diagnosis of hydatid cyst. Albendazol therapy, $10 \mathrm{mg} / \mathrm{kg}$, taken three times a day with main meals in 4-month course separated by intervals of 15 days, was initiated as medical treatment and she also received Dilantin (phenytoin sodium) (100 mg twice a day).

\section{OUTCOME AND FOLLOW-UP}

The patient has been followed 4 months without any neurological deficits.

\section{DISCUSSION}

Intracranial hydatid disease is rare, with reported incidence of $1-2 \%$ of all cases with hydatid disease. ${ }^{8}$ Hydatid disease is endemic in the Middle-East, Mediterranean countries, South America, North Africa and Australia. ${ }^{9}$ Hydatid disease affects the central nervous system in less than $2 \%$ of cases ${ }^{10}$ and is usually diagnosed during childhood. Our 


\section{BMJ Case Reports}

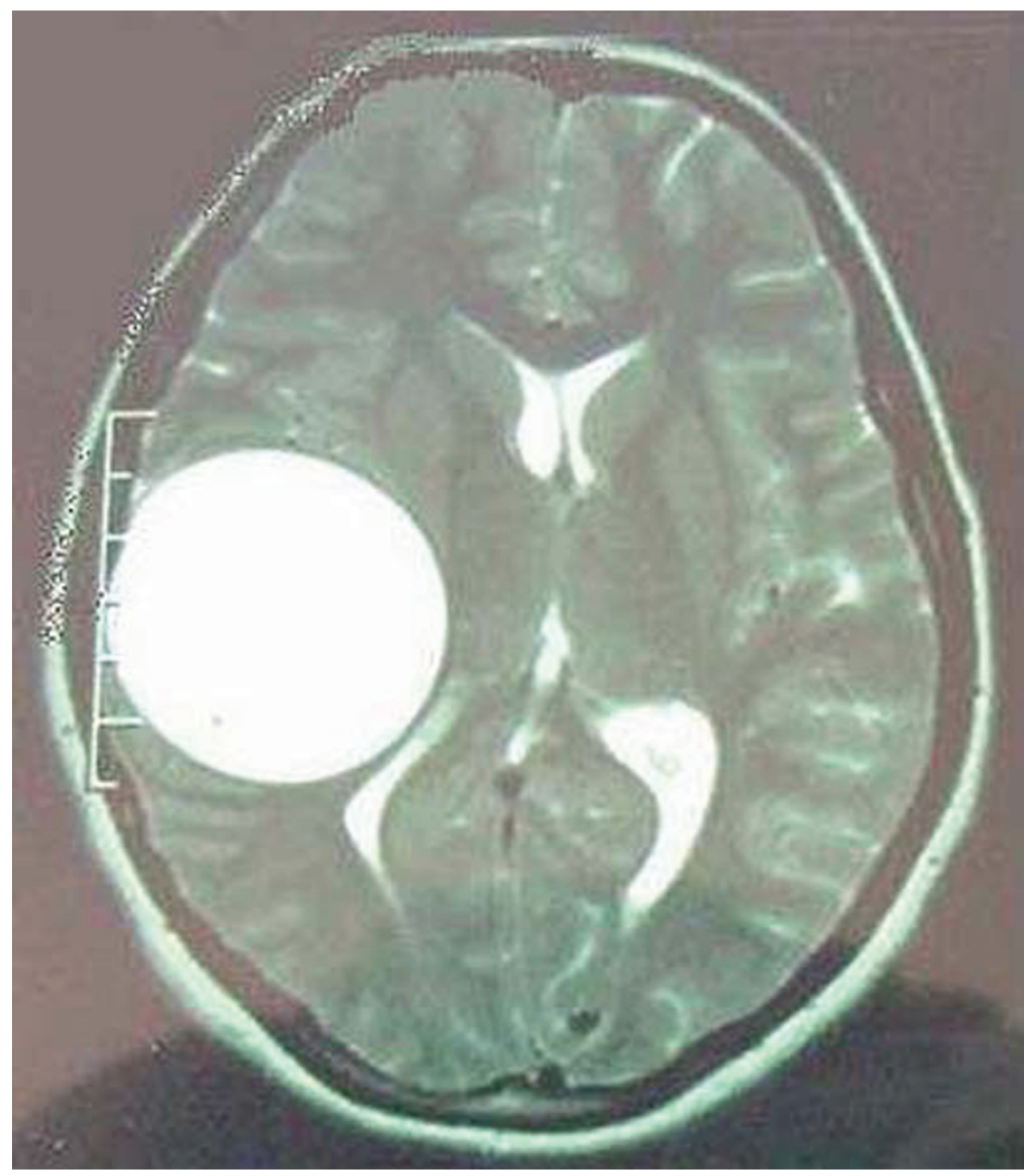

Figure 1 MRI revealed a large cystic left temporal lobe, paraventricular area.

patient was 18 years old. Though in other organs they are multiple, they are usually solitary in brain. ${ }^{11-13}$ The presented case had solitary intracranial cyst. Although hydatid disease may be located anywhere in the brain, it is most frequently located in both hemispheres, particularly in the middle cerebral artery territory. The parietal lobe is the commonest site and was seen in our case in the present study. The patients with intracranial hydatid cysts usually present with focal neurological deficit and features of raised intracranial pressure; the latter may be due to the large size or interference with pathway of CSF flow. This case presented only with severe headache. In young patients, radiography of the skull may demonstrate suture separation, unilateral enlargement of the vault or erosion of the posterior clinoid processes. ${ }^{14}$

Classic CT appearance of $E$ granulosus intracranial hydatid disease is a spherical cystic lesion with sharply defined border and attenuation similar to that of CSF. MRI shows a well-defined oval or cystic mass with signal intensities similar to that of CSF, sometimes with a low-intensity rim. The lesion typically shows no contrast enhancement, and calcifications, usually peripheral, are rare. Cystic lesions with perifocal oedema and rim enhancement can be categorised as complicated. ${ }^{15}$ Intracranial hidatidosis is classified as primary or secondary. The primary disease is caused by direct infestation of the larvae in the brain without demonstrable involvement of other organs. It is suggested that trauma or surgery may induce the parasite to grow in the brain because of damage to the blood-brain barrier. ${ }^{4}$ The primary cysts are fertile as they contain scolices and brood capsules, hence rupture of primary cyst can result in recurrence. The secondary multiple cysts result from spontaneous, traumatic or surgical rupture of the primary intracranial hydatid cyst and they lack brood capsule and scolices. The secondary intracranial hydatid cysts are therefore infertile, and the resultant risk of recurrence after their rupture is negligible. Primary multiple cysts are uncommon and isolated case reports of primary multiple hydatid cysts have appeared in the literature. ${ }^{16} 17$ In view of the finding of the scolex on pathological examination and isolated unilocular brain involvement, our case was a primary brain hydatid cyst. 


\section{BMJ Case Reports}

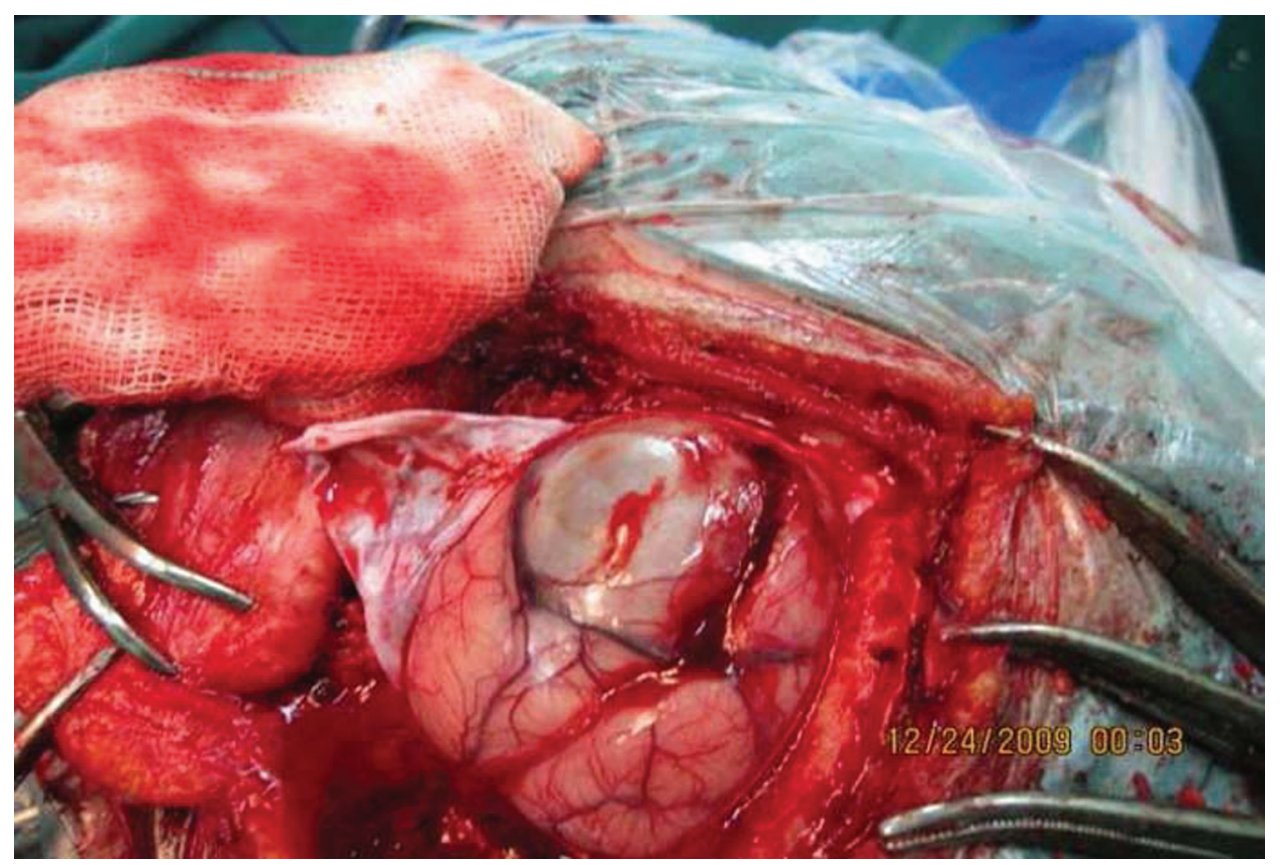

Figure 2 Cystic lesion of right temporal lobe.

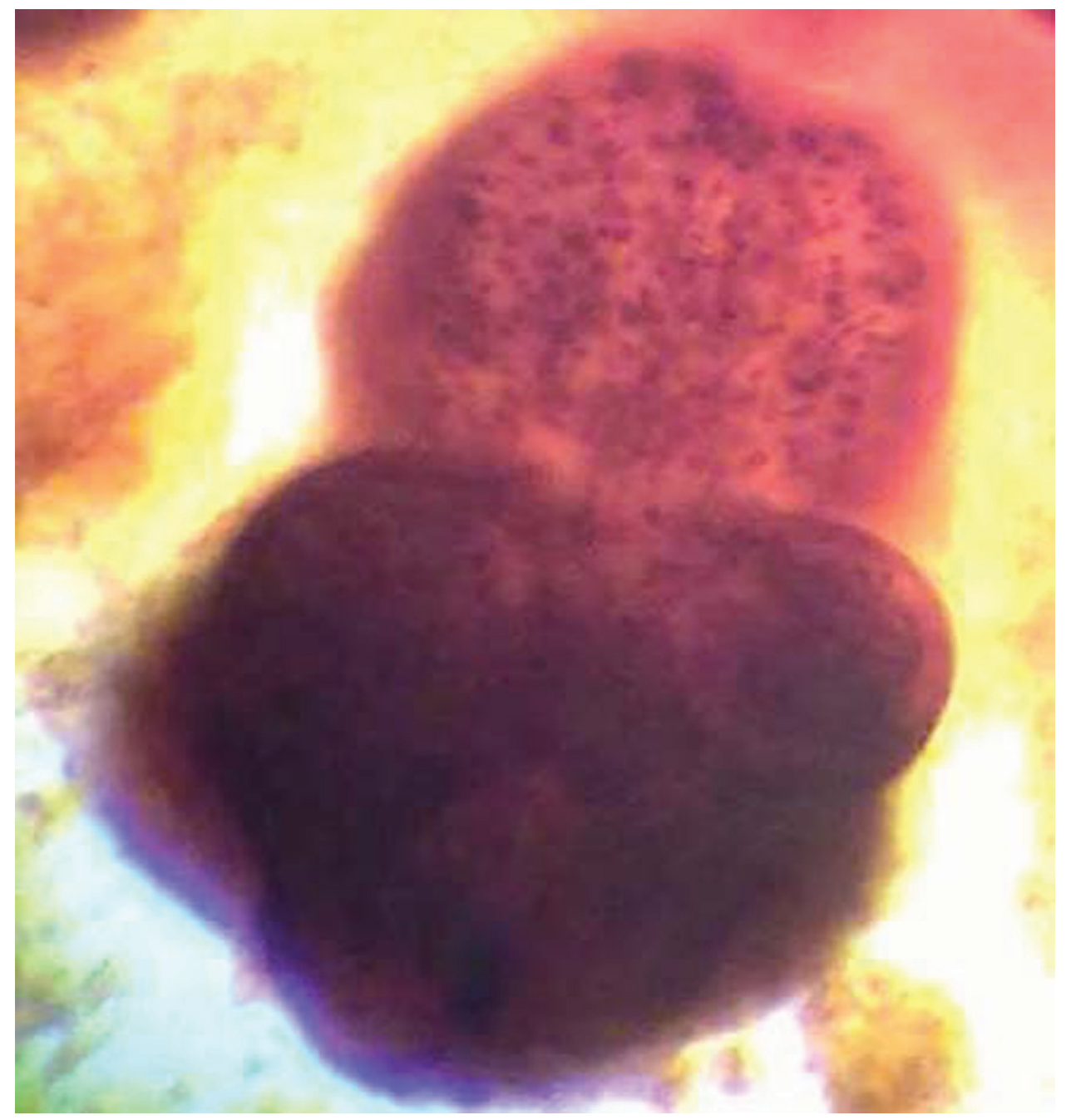

Figure 3 Scolex (Papanicolaou $\times 400)$. 


\section{BMJ Case Reports}

\section{Learning points}

- Although primary brain hydatosis is rare, it may occur in the Middle-East countries and should be considered in the differential diagnosis of brain cyst

- Imaging findings are suggestive and in some cases are diagnostic

- Preoperative accurate diagnosis is very important to prevent inadvertent cyst rupture and its complication

- Intraoperative squash preparation stained with Papanicolaou stain can be very helpful.

Competing interests None.

Patient consent Obtained.

\section{REFERENCES}

1. Fritsche TR, Selvarangan R. Medical parasitology. In: McPherson \& Pincus: Henry's Clinical Diagnosis and Management by Laboratory Methods. 21st edition. Philadelphia, PA: Elsevier 2007:1158

2. Aydin MD, Ozkan U, Altinors N. Quadruplets hydatid cysts in brain ventricles: a case report. Clin Neurol Neurosurg 2002;104:300-2.

3. Ahuja GK, Roy S, Kamla G, et al. Cerebral cysticercosis. J Neurol Sci 1987:35:365-74

4. Menku A, Kurtsoy A, Tucer B, et al. Calcified cerebral hydatid cyst following head trauma: case report. Turk Neurosurg 2004;14:1-2, 36-40.
5. Roquer J, Escudero D, Guelar A, et al. Calcified cerebral hydatid cyst in a patient with abdominal hydatidosis. Med Clin (Barc) 1985;85:458-60.

6. Baysefer A, Erdogan E, Gonul E, et al. Primary multiple cerebral hydatid cysts: case report. Surg Neurol 1998:41:35-7.

7. Ramsey PG, Plorde JJ. Cestode infestation. In: Ramsey PG, Plorde JJ, Fauci AS, Braunwald E, Isslbacher KJ, eds. Harison's Principles of Internal Medicine. New York: McGraw-Hill 1987:825-9.

8. Ersahin $\mathbf{Y}$, Mutluer S, Güzelbag E. Intracranial hydatid cysts in children. Neurosurgery 1993;33:219-24; discussion 224-5.

9. Onal C, Barlas 0, Orakdögen M, et al. Three unusual cases of intracranial hydatid cyst in the pediatric age group. Pediatr Neurosurg 1997:26:208-13.

10. Bükte Y, Kemaloglu S, Nazaroglu H, et al. Cerebral hydatid disease: CT and MR imaging findings. Swiss Med Wkly 2004;134:459-67.

11. Taveras JM. Inflammatory diseases, chapter 6. Neuroradiology. Third edition Philadelphia, PA: Lippincott Williams \& Wilkins 1996:303.

12. El-Shamam 0, Amer T, El-Atta MA. Magnetic resonance imaging of simple and infected hydatid cysts of the brain. Magn Reson Imaging 2001;19:965-74.

13. Gupta S, Desai K, Goel A. Intracranial hydatid cyst: a report of five cases and review of literature. Neurol India 1999:47:214-17.

14. Pedrosa I, Savz A, Arrazola J, et al. Hydatid disease: radiologic and pathologic features and complications. Radiographics 2000;20:795-817.

15. Iyigun 0, Uysal S, Sancak R, et al. Multiple organ involvement hydatid cysts in a 2-year-old boy. J Trop Pediatr 2004;50:374-6.

16. Nurchi G, Francesco F, Montaldo C, et al. Multiple cerebral hydatid disease: case report with magnetic resonance imaging study. Neurosurgery 1992; 30:436-8.

17. Sharma A, Abraham J. Multiple giant hydatid cysts of the brain-case report. Neurosurgery 1982;57:413-15.

This pdf has been created automatically from the final edited text and images.

Copyright 2011 BMJ Publishing Group. All rights reserved. For permission to reuse any of this content visit http://group.bmj.com/group/rights-licensing/permissions.

BMJ Case Report Fellows may re-use this article for personal use and teaching without any further permission.

Please cite this article as follows (you will need to access the article online to obtain the date of publication).

Binesh F, Mehrabanian M, Navabii H. Primary brain hydatosis. BMJ Case Reports 2011;10.1136/bcr.06.2010.3099, date of publication

Become a Fellow of BMJ Case Reports today and you can:

- Submit as many cases as you like

- Enjoy fast sympathetic peer review and rapid publication of accepted articles

Access all the published articles

- Re-use any of the published material for personal use and teaching without further permission

For information on Institutional Fellowships contact consortiasales@bmjgroup.com

Visit casereports.bmj.com for more articles like this and to become a Fellow 